\title{
Purification and characterization of embryo-specific soy urease (Glycine $\max$ ) and its antifungal potential against Paracoccidioides brasiliensis
}

Elisângela Andrade Ângelo ${ }^{1} \oplus$, Tainá Michelle da Cruz $^{2} \oplus$, José Renato Pattaro Júnior²®, Daniele Maria Zanzarin ${ }^{3}$, Franciele Abigail Vilugron Rodrigues ${ }^{4}$, Eduardo Jorge Pilau ${ }^{3} \oplus$, Érika Seki Kioshima $^{4}$, Maria Aparecida Fernandez ${ }^{5} \oplus$, Flavio Augusto Vicente Seixas ${ }^{2+}{ }^{\circ}$

1. Federal Institute of Paraná, Biology laboratory, Umuarama, Brazil.

2. State University of Maringá, Departament of Technology, Umuarama, Brazil.

3. State University of Maringá, Department of Chemistry, Maringá, Brazil.

4. State University of Maringá, Department of Clinical Analysis and Biotechnology, Maringá, Brazil.

5. State University of Maringá, Department of Biotechnology, Genetics and Cell Biology, Maringá, Brazil.

+Corresponding author: Flavio Augusto Vicente Seixas, Phone: +55 44 3621-9300, Email address: favseixas@uem.br

\section{ARTICLE INFO}

Article history:

Received: June 01, 2020

Accepted: October 26, 2020

Published: April xx, 2021
Keywords

1. urease

2. Glycine $\max$

3. fungitoxic

4. Paracoccidioides brasiliensis

ABSTRACT: Ureases are amidohydrolases that catalyze the hydrolysis of urea to ammonia and carbamate. In addition to the enzymatic function, ureases have fungitoxic and insecticidal function, which are independent of their catalytic activity. Soy (Glycine max) has two main urease isoforms: ubiquitous and embryo-specific, the latter is present in beans. In view of the potential applications of ureases, this work aimed to extract, purify, characterize the structure, activity and fungitoxic activity of soy urease against Paracoccidioides brasiliensis. The biochemical characterization was performed, in terms of optimal $\mathrm{pH}$ and temperature, as well as the determination of the Michaelis-Menten constant $\left(\mathrm{K}_{\mathrm{M}}\right)$ and maximum
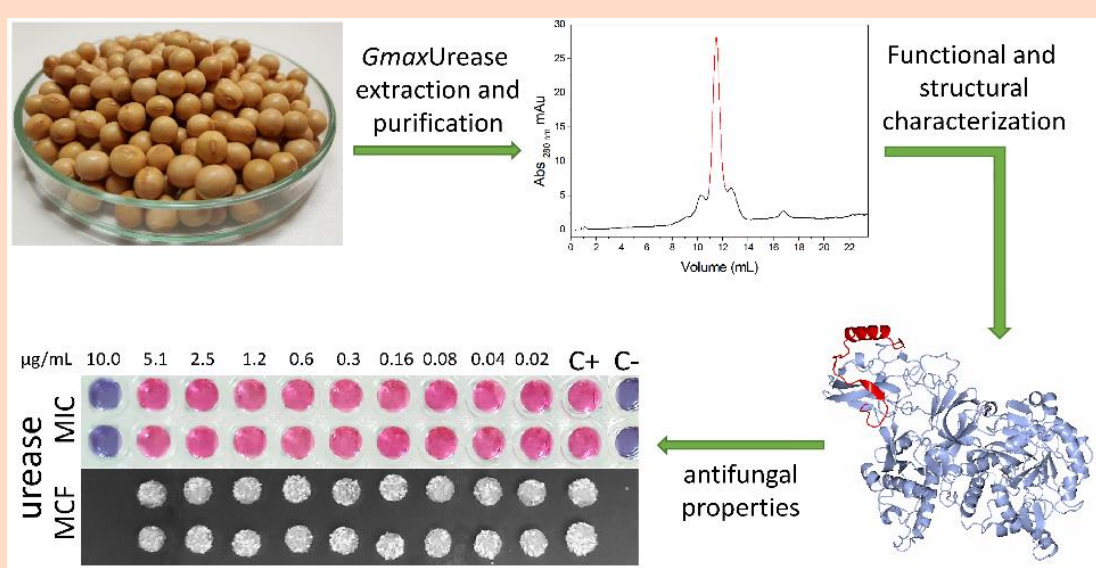

After purification and structural-functional characterization, the embryo-specific soybean urease shows antifungal properties against Paracoccidioides brasiliensis.

velocity $\left(\mathrm{V}_{\max }\right)$. The protein sequence was identified by mass spectrometry and used in computational modeling of the biological structure. The optimum $\mathrm{pH}$ and temperature of the enzyme were 6.5 and $65{ }^{\circ} \mathrm{C}$, respectively, $\mathrm{K}_{\mathrm{M}} 526 \mathrm{mmol} \mathrm{L}^{-1}$ and $\mathrm{V}_{\max } 7.4 \mathrm{mmol} \mathrm{L}$ $\mathrm{NH} 3 \cdot \mu \mathrm{g}_{\text {urease }}{ }^{-1} \cdot \mathrm{s}^{-1}$ and biological unity as a trimer. The antifungal activity assays (in vitro) were promising, showing a fungicidal profile of the urease, with a minimum inhibitory concentration of $10 \mu \mathrm{g} \cdot \mathrm{mL}^{-1}$. This work demonstrated, for the first time, the fungitoxic activity of embryo-specific soy urease against the $\mathrm{Pb} 18$ strain of $P$. brasiliensis. 


\section{Introduction}

Ureases are nickel-dependent amidohydrolases (EC.3.5.1.5) that catalyze the breakdown of the urea amide group into ammonia and carbamate, which decomposes spontaneously in a neutral environment to ammonia and carbon dioxide ${ }^{1,2}$. Ureases are present in bacteria, fungi and vegetables, but are absent in animals ${ }^{3}$. Vegetable ureases play an important role in using urea as a source of nitrogen for the plant. This substrate can originate both from the internal plant metabolism and from an external source, when used as a fertilizer. This substrate can originate either from the internal plant metabolism or from external source when used as fertilizer. In the latter situation, urea is used as nitrogen source, and it can be directly absorbed by the plant or may be used in the form of ammonia or nitrate. When absorbed in the form of ammonia, urea is hydrolyzed outside the plant by ureases present in the soil, which can be of either from vegetable or microbial origin. When absorbed as nitrate, the ammonia hydrolyzed from urea is converted into nitrate by microorganisms present in the soil ${ }^{4-6}$.

The discovery of ureases in vegetables occurred in 1909 by Takeuchi, when studying soybeans, since then, it was discovered that these enzymes are present in all vegetables, in their most diverse tissues ${ }^{6}$. However, such enzymes are especially abundant in vegetables of the families Fabaceae (vegetables), Cucurbitaceae, Asteraceae and Pinaceae ${ }^{7,8}$. The soy (Glycine max) has three urease isoforms: ubiquitous, embryo-specific and SBU-3. Ubiquitous urease is found in the various tissues of soy, while embryo-specific urease is found only in the seed and SBU-3 is found in small amounts, at specific moments of plant development ${ }^{7}$.

More recent studies indicate a new property of plant ureases, related to its toxic role against fungi and insects. It is noteworthy that these toxic activities do not depend on the catalytic activity of this enzyme ${ }^{3,9}$. Due to this property, plant ureases have come to be considered multi proteins ${ }^{2}$, and studies have been carried out in order to explore their fungitoxic ${ }^{10,11}$ and entomotoxic potential ${ }^{12}$. Regarding the fungitoxic potential, studies are mainly focused on phytopathogenic filamentous fungi, such as species from the genera Fusarium and Penicillium ${ }^{2,3}$. There are also some studies with pathogenic mammalian yeasts, such as those of the genus Candida ${ }^{10,13}$. However, there are no studies with dimorphic fungi pathogenic to humans, such as Paracoccidioides brasiliensis.

Paracoccidioides brasiliensis is one of those responsible for causing paracoccidioidomycosis (PCM), an endemic systemic mycosis in Latin
America, frequent in Brazil, Argentina, Colombia and Venezuela. This dimorphic fungus is common at filamentous form in the environment, especially in the soil. Hyphae may contain propagating-infective structures (microconidia) that become yeast-like when inhaled. This form multiplies in the body, causing pathogenesis, which can compromise the functions of several systems, especially the respiratory system ${ }^{14,15}$. In the chronic form, lesions on the oral mucosa, lymph node involvement and, rarely, dermatological lesions may be observed ${ }^{16}$. It is estimated that 10 million people in Latin America are infected by Paracoccidioides spp., with 1-2\% presenting clinical manifestations ${ }^{17}$. Brazil has a high incidence of PCM and annual estimates of its occurrence vary from 0.71 to 3.7 cases for every 100,000 inhabitants. However, there are Brazilian regions where the incidence of PCM is even higher, as in two municipalities in Rondônia, where the incidence rate is 40 cases for every 100,000 inhabitants $^{18}$. Paracoccidioidomycosis is the main responsible for death due to systemic mycoses in Brazil, corresponding to $51.2 \%$ of deaths in this category, between the years 1996 to $2006^{19}$. Even so, it is considered by the World Health Organization (WHO) as a neglected disease ${ }^{17}$.

Regarding the treatments available for human fungal diseases, many antifungals promote adverse effects on the patient, which makes the treatment difficult to continue ${ }^{20}$. In the case of PCM, this situation is aggravated, as the treatments tend to be long, reaching up to 24 months ${ }^{15,18}$.

Thus, in view of the antifungal potential of ureases, as well as the need to develop new drugs against PCM, this work aims to extract and characterize embryospecific soy urease (GmaxUrease), as well as to evaluate its activity (in vitro) against $P$. brasiliensis. Thus, this work can contribute to the development of future technologies based on urease (natural product), aimed at the treatment of topical manifestations of PCM.

\section{Experimental}

\subsection{Extraction of embryo-specific soy urease}

The protocol for enzyme extraction was guided by the method proposed by Bracco et al. $^{21}$ with modifications. The soy flour was obtained from the soybean seed Bayer 26B42 ground. Then, $25 \mathrm{~g}$ of the flour was defatted by double washing with chloroform in an ice bath under stirring for $30 \mathrm{~min}$, followed by filtration on Whatman paper. The defatted extract was 
used for protein extraction by means of constant agitation with $20 \%(\mathrm{w} / \mathrm{v})$ of $20 \mathrm{mmol} \mathrm{L}^{-1}$ phosphate buffer with $1 \mathrm{mmol} \mathrm{L}^{-1} \beta$-mercaptoethanol, $\mathrm{pH} 7.5$ at $4{ }^{\circ} \mathrm{C}$ for $12 \mathrm{~h}$. The soluble protein fraction (supernatant) was separated by centrifugation at 30,000 $\mathrm{g}$ for $30 \mathrm{~min}$. This fraction was considered the crude extract and $10 \mu \mathrm{L}$ of the cocktail of a plant protease inhibitor was added to it (Sigma P9599, USA).

\subsection{Purification of embryo-specific soy urease}

Purification of GmaxUrease was done using chromatography and centrifugation techniques. Initially, a gel filtration chromatography column containing Sephadex G-25 resin $(25.0 \times 1.5 \mathrm{~cm})$ and phosphate buffer $\left(20 \mathrm{mmol} \mathrm{L}^{-1}\right)$ with $100 \mathrm{mmol} \mathrm{L}^{-1}$ $\mathrm{NaCl}$ and $\mathrm{pH} 7.5$ as mobile phase and elution flow of $1.0 \mathrm{~mL} \cdot \mathrm{min}^{-1}$ monitored by spectrophotometer at 280 $\mathrm{nm}$. The fraction that showed ureolytic activity was concentrated by means of ultrafiltration using Amicon filter $30 \mathrm{kDa}$ cutoff, at $1,000 \mathrm{~g}$ for $20 \mathrm{~min}$. This fraction was called G25 and $10 \%$ glycerol (q.s.) was added to it.

The G-25 fraction was subjected to a new size exclusion chromatography in a column with Sephacryl HS-200 resin $(60.0 \times 1.5 \mathrm{~cm})$, in a fast protein liquid chromatography (FPLC) system model Äkta Prime (GE Lifesciences, USA). The protein fractions were eluted using the phosphate buffer described in the previous step, with a flow rate of $0.5 \mathrm{~mL} \cdot \mathrm{min}^{-1}$. The fraction that showed ureolytic activity was collected and concentrated by means of ultracentrifugation. At the end, $10 \%$ glycerol was added to the concentrate (q.s.), which was identified as the Sephacryl fraction.

Finally, the Sephacryl fraction was subjected to a third size exclusion chromatography, using a Superdex-200 10/300 column (GE Lifesciences, USA), using other FPLC filtration system model Äkta Pure M (GE Lifesciences, USA). The elution and concentration conditions were the same as in the previous steps. At the end, the concentrate received $10 \%$ glycerol (q.s.) again and was called Superdex fraction.

\subsection{Verification of purity and molecular weight}

The purity of the eluted fractions was verified using $12 \%$ SDS-PAGE electrophoresis, stained with Coomassie blue ${ }^{22}$. Electrophoresis was also used to estimate the molecular weight of the bands, using the marker Sigma-Marker ColorBurst (Sigma, C1992, USA) by means of ImageQuant-TL 8.1 program (GE- lifescience, USA). This program was also used to estimate the percentage of urease in the sample.

The molecular weight (MW) of the biological unity of soybean urease, under nondenaturing conditions, was calculated using the gel filtration method by a Superdex-200 10/300 column (GE Lifesciences). The calibration curve was constructed with the low and high MW gel filtration calibration kit standards (GE Lifesciences), following the manufacturer's recommendations. The proteins were eluted in isocratic mode using $50 \mathrm{mmol} \mathrm{L}{ }^{-1}$ phosphate buffer + $150 \mathrm{mmol} \mathrm{L}^{-1} \mathrm{NaCl}, \mathrm{pH} 7.2$ at room temperature, in a flow rate of $0.5 \mathrm{~mL} \cdot \mathrm{min}^{-1}$. The absorbances were monitored at 214 and $280 \mathrm{~nm}$ and elution volumes for each protein were measured and converted to $K_{a v}$ (Eq. 1) and plotted against the logarithm of the respective molecular weights $(\log \mathrm{MW})$.

$$
K_{a v}=\frac{v_{e}-v_{o}}{v_{c}-v_{o}}
$$

where $V e=$ elution volume, $V o=$ column void volume and $V c=$ geometric column volume.

\subsection{Determination of protein concentration and ureolytic activity}

The protein concentration of the crude extract, as well as of the G-25, Sephacryl and Superdex fractions, was determined according to Bradford ${ }^{23}$, using bovine serum albumin as a standard. The assays were done in duplicate and triplicate if necessary. The measurement of ureolytic activity was performed by quantifying the ammonia (product) using Nessler's reagent ${ }^{24}$. An enzyme unit (U) was considered to be the amount of enzyme needed to produce $1 \mu \mathrm{mol} \mathrm{L^{-1 }}$ of ammonia per minute ${ }^{25}$.

\subsection{Protein identification by liquid chromatography-mass spectrometry $\left(L C-M S^{E}\right)$}

To determine whether the protein obtained was embryo-specific soy urease (GmaxUrease), peptide sequence identification was performed by liquid chromatography-mass spectrometry (LC-MS ${ }^{\mathrm{E}}$ ) analysis. The protein band extracted from the SDSPAGE, which had molecular mass corresponding to the estimated theoretical value for urease, was digested in the cropped gel band with trypsin, according to the Shevchenko protocols ${ }^{26,27}$. 
The analysis was performed using Acquity UPLC M-Class System ultra-high performance liquid chromatography (Waters, Milford, MA) coupled a time-of-flight high resolution mass spectrometry (Xevo G2, Waters) equipped with an electrospray ionization source. Chromatographic separation was performed on an Acquity UPLC M-Class HSS T3 column, with particle size $1.8 \mu \mathrm{m}, 300 \mu \mathrm{m} \times 150 \mathrm{~mm}$ (Waters, UK), and flux of $6 \mu \mathrm{L} \cdot \mathrm{min}^{-1}$. The solvent gradient mixture: A $\left(\mathrm{H}_{2} \mathrm{O} / 0.1 \%\right.$ formic acid; $\left.\mathrm{v}: \mathrm{v}\right)$ and $\mathrm{B}$ (acetonitrile/ $0.1 \%$ formic acid; v/v) was: $3 \%$ B $0-1$ min, 40\% B 1-80 min, 97\% B 80-90 min, holding 97\% B for $90-97 \mathrm{~min}, 3 \% \mathrm{~B}$ for $97-100 \mathrm{~min}$, and holding $3 \% \mathrm{~B}$ for $100-103 \mathrm{~min}$ at $40{ }^{\circ} \mathrm{C}$. The capillary voltage was operated in the positive mode at $3.0 \mathrm{kV}$. In the cone, the voltage was adjusted to $40 \mathrm{~V}$ and the gas to $600 \mathrm{~L} \cdot \mathrm{h}^{-1}$ at $400{ }^{\circ} \mathrm{C}$. Data were collected in the range between 50 to $2000 \mathrm{~m} / z$ using $\mathrm{MS}^{\mathrm{E}}$ acquisition mode, scan time $0.5 \mathrm{sec}$ and collision energy ramp $15-45 \mathrm{~V}$.

After analysis, the data (.raw) were processed/analyzed using the ProteinLynx Global ServerTM 3.0.3 software, and the revised soy database (Glycine max, Uniprot). The parameters used for searching the database were: cleavage specificity, trypsin with 1 missed cleavage allowed, min fragment ion matches per peptide $=2$, min fragment ion matches per protein $=5$, min peptide matches per protein $=1$, fixed modifier reagent: carbamidomethyl $\mathrm{C}$, variable modifier reagents: oxidation $\mathrm{M}$.

\subsection{Structural modeling of embryo-specific soy urease}

The amino acid sequence of soy urease identified by LC-MS ${ }^{\mathrm{E}}$ deposited in Uniprot (id: i1k3k3) was used to search for template structures in the protein data bank (PDB), by BlastP program. The urease structure of Canavalia ensiformis (pdb id: $31 \mathrm{a} 4)^{28}$ was chosen and used as a template. The modeling was performed using the Modeller v9.24 software package ${ }^{29}$, where 2,100 models of urease were generated in the presence of the nickel cofactor and four residues with posttranscriptional modifications. Only one chain was modeled, and the homotrimer and homohexamer structures generated by symmetry operations. The final model was chosen based on the Modeller DOPE score and also by stereochemical quality using the Procheck $\operatorname{program}^{30}$.

\subsection{Effect of $\mathrm{pH}$ and temperature on enzyme activity}

The effect of $\mathrm{pH}$ on ureolytic activity was estimated using the Britton-Robinson $0.04 \mathrm{~mol} \mathrm{~L}^{-1}$ buffer $^{31}$, in the range of 5.0 to 9.0 . Firstly, a single buffer was made in the presence of 3\% urea and the $\mathrm{pH}$ adjusted according to the test. Subsequently, incubation was performed with $2.7 \mu \mathrm{g} \cdot \mathrm{mL}^{-1}$ of urease at $55{ }^{\circ} \mathrm{C}$ for 15 $\min$.

The effect of temperature on the rate of urea production was determined at constant enzyme concentrations. An amount of $2.7 \mu \mathrm{g} \cdot \mathrm{mL}^{-1}$ urease was incubated in $0.2 \mathrm{~mol} \mathrm{~L}^{-1}$ phosphate buffer, $3 \%$ urea, $\mathrm{pH} \mathrm{6.5,} \mathrm{for} 15 \mathrm{~min}$. The incubation temperatures ranged between 25 to $85{ }^{\circ} \mathrm{C}$, the experiments were carried out in duplicate, discounting the urea degradation due to temperature, using a negative control. The ammonia generated was quantified using the Nessler methodology, in a NanoDrop system (Thermo Scientific) in all activity assays.

\subsection{Effect of different substrate concentrations}

The assays were performed at urea concentrations ranging from 0 to $235 \mathrm{mmol} \mathrm{L}^{-1}, \mathrm{pH} 6.5$, temperature of $65{ }^{\circ} \mathrm{C}$ and incubation time of $5 \mathrm{~min}$, followed by the determination of ureolytic activity. The enzyme concentration used in these assays was $2.7 \mu \mathrm{g} \cdot \mathrm{mL}^{-1}$. The results were plotted as function of substrate concentration (Michaelis-Menten plot) and doublereciprocal (Lineweaver-Burk plot), through which was possible to calculate the Michaelis-Menten apparent constant $\left(\mathrm{K}_{\mathrm{M}}\right)$ and $\mathrm{V}_{\max }$.

\subsection{Antifungal activity against $P$. brasiliensis}

The fungitoxic activity of urease was evaluated against $P$. brasiliensis, $\mathrm{Pb} 18$ strain, by means of serial broth microdilution assay, according to the methodology of Clinical and Laboratory Standards Institute $^{32,33}$, with modifications as described by Rodrigues-Vendramini ${ }^{34}$. The urease concentration ranged between 0.02 to $10 \mu \mathrm{g} \cdot \mathrm{mL}^{-1}$. The antifungal agent itraconazole was used as a negative control at a concentration of $1 \mu \mathrm{g} \cdot \mathrm{mL}^{-1}$. An assay containing only the microorganism and the culture medium was used as positive control, in order to verify the viability of the strain. In addition, bovine serum albumin (BSA) was evaluated at concentrations between 0.2 to $104.4 \mu \mathrm{g} \cdot \mathrm{mL}^{-1}$, to assess whether any inhibitory activity could be due to osmotic origin. The inoculum 
for the assays were grown in RPMI 1640 medium, prepared with a concentration of $105 \mathrm{UFC} \cdot \mathrm{mL}^{-1}$, standardized by counting in a Neubauer chamber and diluted 1:2 in the wells of a 96-well microplate. After inoculation, the microplates were incubated at $37{ }^{\circ} \mathrm{C}$ for 7 days, and on the sixth day $20 \mu \mathrm{L}$ of $0.02 \%$ resazurin was added to each well, as an indicator of metabolic activity. Then, the plates were again incubated for $24 \mathrm{~h}$.

To identify the minimum inhibitory concentration (MIC), a visual reading of the color change of the wells was performed. To identify the minimum fungicidal concentration (MFC), growth was evaluated in solid medium. For this purpose, $20 \mu \mathrm{L}$ aliquots of the wells were transferred to plates containing brain heart infusion agar, followed by superficial inoculation (spread plate). The plates were kept at $35{ }^{\circ} \mathrm{C}$ for $48 \mathrm{~h}$ and, after this period, the possible formation of colonies was observed. The MFC was considered the lowest concentration in which there was no growth in the plate ${ }^{35}$.

\section{Results and discussion}

\subsection{Protein purification}

The extraction of proteins from defatted soy flour resulted in a sample containing $18.79 \mathrm{mg} \cdot \mathrm{mL}^{-1}$ of total proteins. The purification carried out using centrifugation and chromatographic methods of gel filtration resulted in a yield of $18.23 \%$ and a purification factor of 5.92, for which steps are summarized in Tab. 1. Although the yield was lower than reported by other authors ${ }^{25}$, the specific activity was about 5 times higher. This is because the soy used probably had a high initial urease content. Enzyme unit values are compatible with other study with embryospecific soy urease, which showed values between 24,630 and 141,350 of enzyme units ${ }^{36}$. It is interesting to note that even in studies with heterologous expression of urease, the concentration in the culture medium is around $2 \mu \mathrm{g} \cdot \mathrm{mL}^{-1}$ and $5 \mu \mathrm{g} \cdot \mathrm{mL}^{-1}$ after purification and concentration respectively ${ }^{13}$. Thus, the results presented here are promising.

Table 1. Summary of GmaxUrease purification steps from soybean seeds.

\begin{tabular}{|l|c|c|c|c|c|}
\hline Step & $\begin{array}{c}\text { Proteins / } \\
\text { mg.mL- }\end{array}$ & $\begin{array}{c}\text { Enzyme unity / } \\
\mathbf{U}\end{array}$ & $\begin{array}{c}\text { Specific activity } \\
\text { /U·.mg-1 }\end{array}$ & Yield / \% & $\begin{array}{c}\text { Purification } \\
\text { factor }\end{array}$ \\
\hline Crude extract & 18.79 & $96,764.72$ & $5,149.80$ & 100.00 & 1.00 \\
\hline G25 & 3.96 & $36,130.19$ & $9,123.79$ & 37.34 & 1.77 \\
\hline Sephacryl & 1.69 & $25,150.22$ & $14,881.78$ & 25.99 & 2.89 \\
\hline Superdex & 0.58 & $17,638.42$ & $30,411.07$ & 18.23 & 5.90 \\
\hline
\end{tabular}

The urease purification chromatograms in the Sephadex G25, Sephacryl HS-200 and Superdex S-200 columns, pointing the peaks that showed ureolytic activity, are shown in Fig. 1a-c. It is noteworthy that, in the step performed using Superdex S-200 column, which has analytical grade, only the maximum point of the eluted peak was collected in the process, in order to ensure better purification. However, this fact may have contributed to the lower yield, when compared to another urease purification studies ${ }^{25}$.

The SDS-PAGE showed a band with approximately $90 \mathrm{kDa}$. According to data in the literature, ureases correspond to 0.2 to $0.3 \%$ of soluble proteins that can be extracted ${ }^{37}$. Additional attempts to purify urease in a Q-Sepharose anion exchange column (GE Lifesciences) resulted in almost total loss of ureolytic activity, even after supplementation of the eluted fraction with nickel. Thus, the purification process was all carried out using different gel filtration columns. The calculated MW for the protein in solution using the elution volume of the Superdex S-200 column was $272.2 \mathrm{kDa}$, compatible as a trimer in solution (Fig. 1d). 

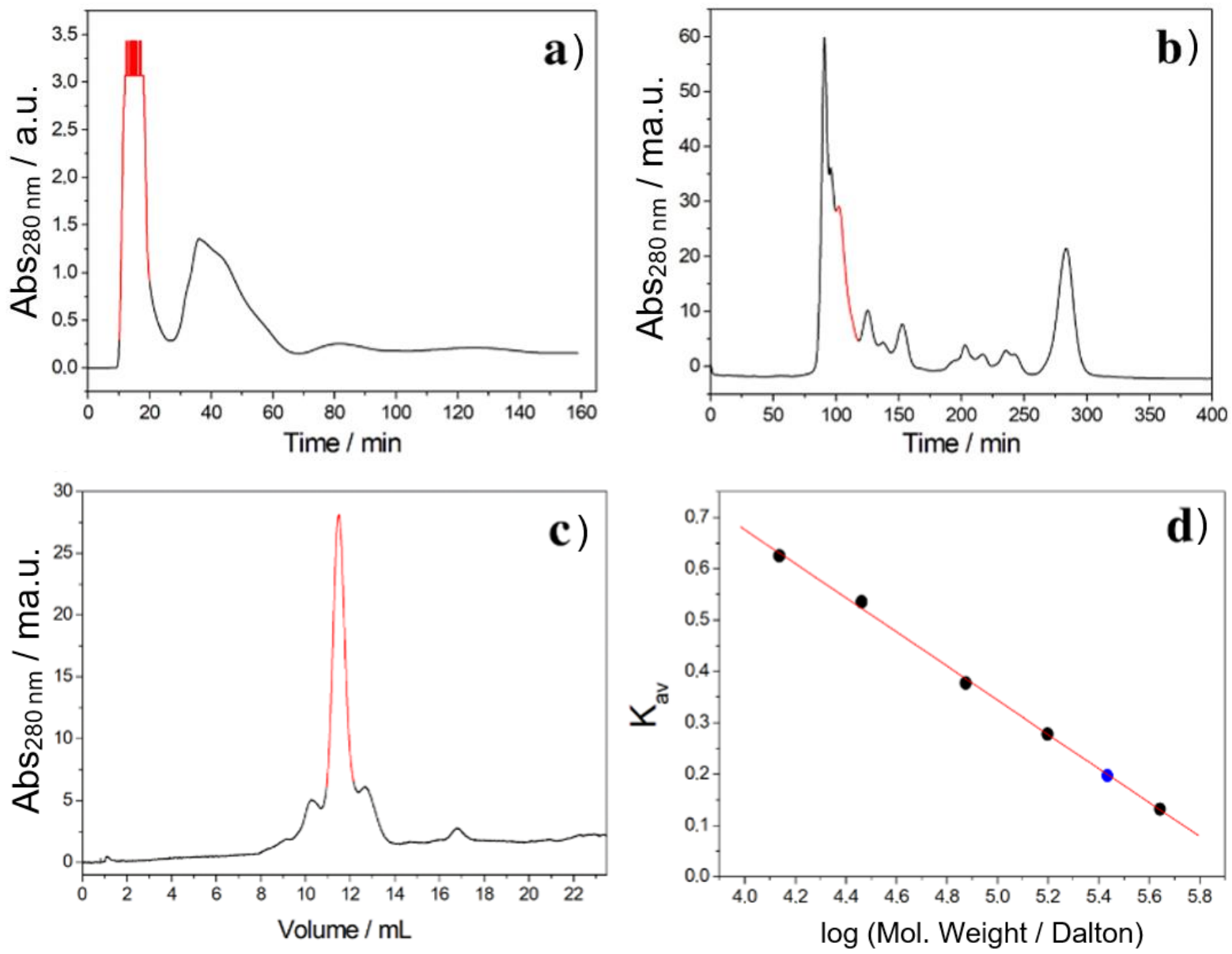

Figure 1. Chromatograms of the GmaxUrease purification steps. The red lines indicate the peaks that showed ureolytic activity and were collected. (a) Sephadex G25, (b) Sephacryl HS-200, (c) Superdex S-200. The volume referring to the peak of the Superdex S-200 column was used to estimate the molecular weight of GmaxUrease in figure (d). In this assay, $500 \mu \mathrm{L}$ of the protein mix with known molecular weights (black dots) was applied: Ferritin $(440 \mathrm{kDa})$, aldolase $(158 \mathrm{kDa})$, canalbumin $(75 \mathrm{kDa})$, carbonic anhydrase $(29 \mathrm{kDa})$ and ribonuclease $(13.7 \mathrm{kDa})$, in the Superdex-200 10/300 column. To estimate the MW of GmaxUrease, $500 \mu \mathrm{L}$ of protein was applied at a concentration of $1 \mathrm{mg} \cdot \mathrm{min}^{-1}$, and its elution volume converted to $\mathrm{K}_{\mathrm{av}}$ (blue dot). The elution flow was $0.5 \mathrm{mg} \cdot \mathrm{min}^{-1}$ at room temperature of $\sim 23{ }^{\circ} \mathrm{C}$. The estimated MW was $\sim 272.2 \mathrm{kDa}$, compatible with a trimer in solution. The linear regretion $(y=a+b x)$ parameters are: $a=2.00381, b=-0.33196$ and $\mathrm{R}=-0.99912$. The $\mathrm{K}_{\mathrm{av}}$ for GmaxUrease is $(y=0.19961)$.

\subsection{Protein identification using data-independent analysis (MSE)}

Mass spectrometry was performed using an electrospray ionization source and time of flight (TOF) analyzer, which allow proteomic analysis, since it is possible to form fragments with various charges and there is no molecular weight limitation for the analyzer. Thus, the protein on the electrophoresis gel band was digested by trypsin to obtain peptides for injection into the mass spectrometer, followed by comparative analysis using Uniprot database. The processing results data showed different levels of coverage of urease sequences (several Uniprot ids) without occurrence of false positives. In view of the high molecular weight of this protein, the percentage found is suitable for its identification, considering that in other study the percentage of $20 \%$ was sufficient for this identification ${ }^{13}$. Table 2 summarizes the results of the mass spectrometry analysis and shows that all ranked proteins resulting from processing refer to soy urease. The alignment of the resulting sequences, let to the identification of the protein with Uniprot id: i1 $3 \mathrm{k} 3$ with theoretical molecular mass of 90,338 Da being the most conserved, therefore, being used for modeling the protein structure. 
Table 2. Results from mass spectrometry analysis of the band considered as GmaxUrease extracted from SDSPAGE.

\begin{tabular}{|c|c|c|c|c|}
\hline Protein description (Uniprot) & Uniprot id & Score & Aligned peptides / \% & $\begin{array}{c}\text { Theoretical molecular } \\
\text { weight / Da }\end{array}$ \\
\hline Urease $\mathrm{OS}=$ Glycine soja & a0a0b2rjr9 & 1211 & 28.11 & 90,046 \\
\hline Urease $\mathrm{OS}=$ Glycine $\max$ & i1k3k3 & 1209 & 26.22 & 90,338 \\
\hline Urease $\mathrm{OS}=$ Glycine soja & a0a445kny1 & 1209 & 26.22 & 90,360 \\
\hline Urease $\mathrm{OS}=$ Glycine $\max$ & q7xac5 & 1026 & 18.62 & 90,157 \\
\hline Urease (Fragment) OS $=$ Glycine $\max$ & q41214 & 726 & 21.37 & 14,091 \\
\hline & \multicolumn{3}{|c|}{ Urease $\mathrm{OS}=$ Glycine soja; Uniprot ID $\mathrm{i} 1 \mathrm{k} 3 \mathrm{k} 3$} \\
\hline & Species & \multicolumn{3}{|c|}{ Glycine max (Soybean) (Glycine hispida) } \\
\hline \multicolumn{2}{|l|}{ Peptide numbers } & \multicolumn{3}{|c|}{$\frac{\text { Glycine max (Soybean) (Glycine hispida) }}{17}$} \\
\hline \multirow{17}{*}{ Peptide sequences } & & \\
\hline & & \multicolumn{3}{|c|}{ LNIAAGTAVR } \\
\hline & & \multicolumn{3}{|c|}{ GPLQPGESDNDNFR } \\
\hline & & \multicolumn{3}{|c|}{ GGVVAWADMGDPNASIPTPEPVK } \\
\hline & & \multirow{2}{*}{\multicolumn{3}{|c|}{ NYFLF }} \\
\hline & & \multicolumn{2}{|c|}{ GSSSKPDELHDIIK } & \\
\hline & & \multicolumn{3}{|c|}{ DGLIVSIGK } \\
\hline & & \multicolumn{3}{|c|}{ EGTIAAEDILHDIGAISIISSDSQAMGR } \\
\hline & & \multicolumn{3}{|c|}{ GGNGIADGQVNETNLR } \\
\hline & & \multicolumn{3}{|c|}{ NAVILK } \\
\hline & & \multicolumn{3}{|c|}{ YGPTTGDK } \\
\hline & & \multirow{2}{*}{\multicolumn{3}{|c|}{$\begin{array}{c}\text { ADIGIK } \\
\text { ATTCTPAPSOMK }\end{array}$}} \\
\hline & & & \multicolumn{2}{|c|}{ ATTCTPAPSQMK } \\
\hline & & \multicolumn{3}{|c|}{ VEAVGNVR } \\
\hline & & \multicolumn{3}{|c|}{ EEEDASEGITGDPDSPFTTIIPREEYANK } \\
\hline & & \multicolumn{3}{|c|}{ EDNRIPGEIIYGDGSLVLNPGK } \\
\hline & & \multicolumn{3}{|c|}{ RVEAVGNVR } \\
\hline \multicolumn{2}{|l|}{ Protein mass (MW) } & \multicolumn{3}{|c|}{90,338} \\
\hline \multicolumn{2}{|l|}{ Sequence coverage* } & \multicolumn{3}{|c|}{$26.22 \%$} \\
\hline $\begin{array}{l}\text { MKLSPREVEKLGLHNAGYLAQKRLA } \\
\text { EATFPDGTKLVTVHDPISCEHGDLG }\end{array}$ & $\begin{array}{l}\text { ILRLNYTEAV } \\
\text { LFGSFLPVP }\end{array}$ & $\begin{array}{l}\text { IATQII } \\
\text { DKFAFI }\end{array}$ & $\begin{array}{l}\text { EARDGEKTVAQLMCIGK } \\
\text { EDNRIPGEIIYGDGSLV }\end{array}$ & $\begin{array}{l}\text { GRRQVLPEVQHLLNAVQV } \\
\text { GKNAVILKVVSNGDRPIO }\end{array}$ \\
\hline VGSHYHFIEVNPYLTFDRRKAYGMR & IIAAGTAVRE & GDSKS & LVRIGGNKVIRGGNGII & VNETNLREAMEAVCKRGF \\
\hline GHKEEEDASEGITGDPDSPFTTIIP & EYANKYGPT & DKIRL & TDLFAKIEKDFALYGDE & GGGKVLRDGMGQSCGHPP \\
\hline AISLDTVITNAVI IDYSGI IKADIG & EDGLIVSIGK & NPDIMI & VFFNMI I GANTEVIAGE & VTAGAIDCHVHYICPQLV \\
\hline DEAISSGITTLVGGGTGPTAGTRAT & TPAPSQMKL & QSTDD & LNFGFTGKGSSSKPDEI & IKAGAMGLKLHEDWGSTP \\
\hline AAIDSCLTVADQYDIQINIHTDTLN & GFVEHSIAA & GRTIH! & HSEGAGGGHAPDI IKVC & KNVLPSSTNPTRPLTLNTI \\
\hline DEHLDMLMVCHHLNREIPEDLAFAC & IREGTIAAE & LHDIG & SIISSDSQAMGRVGEVI & WQTANKMKVQRGPLQPGE \\
\hline SDNDNFRIKRYIAKYTINPAIANGF & YVGSVEVGK & DLVMWI & SFFGAKPEMVIKGGVVF & MGDPNASIPTPEPVKMRP \\
\hline $\begin{array}{l}\text { MFGTLGKAGGALS IAFAAVDQRVHA } \\
\text { RNYFLF }\end{array}$ & GLNKRVEAV & VRKLTI & DMKLNDSLPQITVDPDI & TTADGEVLTSFATTFVPLS \\
\hline
\end{tabular}

*functional protein without $\mathrm{N}$-terminal signal peptide.

\subsection{Analysis of enzyme activity}

Different enzyme batches were extracted from different soy samples, which guaranteed biological reproducibility. Then, in order to characterize the functional parameters of the protein, activity assays were carried out under different $\mathrm{pH}$ and temperature conditions (Fig. 2). The enzyme showed better activity at $\mathrm{pH} 6.5$ and temperature close to $65{ }^{\circ} \mathrm{C}$. Literature reports that the optimal $\mathrm{pH}$ for ureases, in general, ranges between 5.0 and 8.0, depending on the species and even the isoform ${ }^{4}$. However, for ubiquitous soy urease, there are two peaks of activity, one around 5.5 and the other at $9.0^{21,38}$; however, there is a study that reports optimal activity for embryo-specific soy urease at $\mathrm{pH} 6.1^{39}$. Regarding the temperature, literature also reports variation, however, it is usually around $0{ }^{\circ} \mathrm{C}^{38}$.

The substrate concentration at maximum urease activity was close to $190 \mathrm{mmol} \mathrm{L}^{-1}$ (Fig. 3a). Beyond this concentration, activity begins to decrease 
gradually, a fact that can be explained by a mechanism of substrate inhibition ${ }^{40}$. Thus, the Michaelis-Menten equation was adjusted to the experimental points and provided $\mathrm{K}_{\mathrm{M}}$ of $109 \pm 23 \mathrm{mmol} \mathrm{L} \mathrm{L}^{-1}$ and $\mathrm{V}_{\max }$ of $2.5 \pm$ $0.4 \mathrm{mmol} \mathrm{L}{ }^{-1} \mathrm{NH}^{2} \cdot \mu_{\mathrm{g}_{\text {urease }}}{ }^{-1} \cdot \mathrm{s}^{-1}$ (Fig. 3a). Values quite different from those obtained by the double-reciprocal plot (Fig. 3b), which presented $\mathrm{K}_{\mathrm{M}}$ of $\sim 526 \mathrm{mmol} \mathrm{L}^{-1}$ and $\mathrm{V}_{\max }$ of $7.4 \mathrm{mM} \mathrm{NH}_{3} \cdot \mu \mathrm{g}_{\text {urease }}{ }^{-1} \cdot \mathrm{s}^{-1}$. However, Pisum sativum urease showed the same substrate inhibitory effect, and its $\mathrm{K}_{\mathrm{M}}$ found by adjusting the MichaelisMenten equation to data points was close to $100 \mathrm{mmol} \mathrm{L}^{-1}$ but was $500 \mathrm{mmol} \mathrm{L}{ }^{-1}$ when calculated by the double-reciprocal plot at $\mathrm{pH} 7.5^{25}$. These values are very similar to those found in this work.
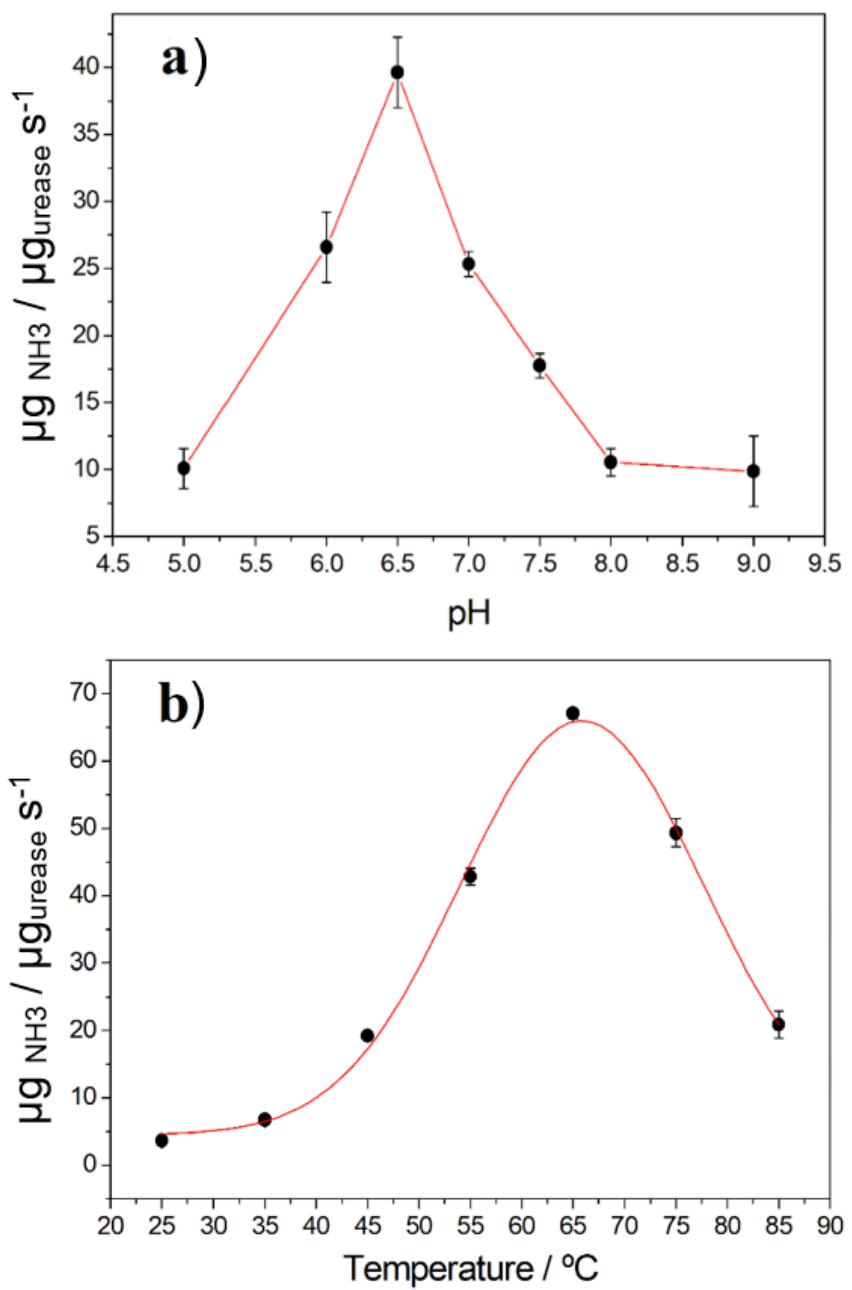

Figure 2. Effects of changes in the experimental conditions on the catalytic activity of GmaxUrease. (a) Effect of pH using $0.04 \mathrm{~mol} \mathrm{~L}^{-1}$ Britton-Robinson buffer, with $3 \%$ urea and a temperature of $55{ }^{\circ} \mathrm{C}$. (b) Effect of temperature using $0.2 \mathrm{~mol} \mathrm{~L}^{-1}$ phosphate buffer, 3\% urea, $\mathrm{pH}$ 6.5. In both assays, the enzyme concentration was $2.7 \mu \mathrm{g} \cdot \mathrm{mL}^{-1}$. Each point on the graph represents the average of two repetitions.
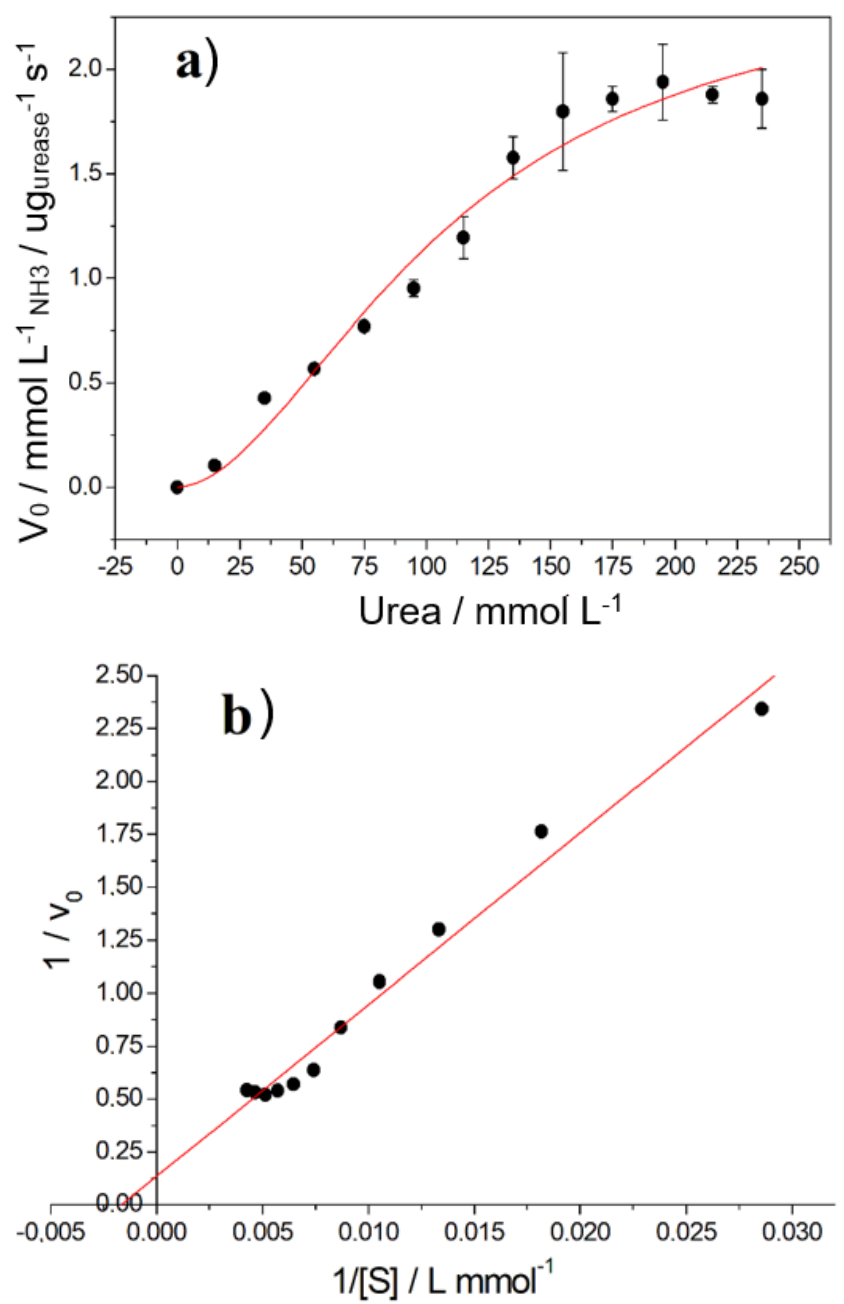

Figure 3. Effect of the substrate (urea) concentration on the catalytic activity of GmaxUrease, using $0.2 \mathrm{~mol} \mathrm{~L}^{-1}$ phosphate buffer, $\mathrm{pH}$ of 6.5 at $65{ }^{\circ} \mathrm{C}$ temperature. (a) Michaelis-Menten plot showing a tendency of decrease in velocity at urea concentrations higher than $195 \mathrm{mmol} \mathrm{L}^{-1}$. The red line represents the best fit of Michaelis-Menten equation to the experimental data points. (b) Double-reciprocal plot for estimating $\mathrm{K}_{\mathrm{M}}$ and $\mathrm{V}_{\max }$ values. Each point on the graphs represents the average of two repetitions.

\subsection{Evaluation of antifungal activity}

We carried out microbiological assays aiming to evaluate the antifungal property of GmaxUrease against the human pathogenic fungus $P$. brasiliensis. Until then, this property of urease was never evaluated against this fungal. The MIC and MFC values obtained were $\sim 10 \mu \mathrm{g} \cdot \mathrm{mL}^{-1}$ of urease. Bovine serum albumin was used as negative control in order to verify a possible inhibitory osmotic effect due to protein concentration; however, such influence did not occur 
(Fig. 4). The MIC/MFC values found are promising, because, although this is the first study that demonstrates the urease antifungal activity against $P$. brasiliensis, when comparing this result to similar ones that used other fungi, such as the yeast Candida albicans, the MIC values ranged between 240 to $150 \mu \mathrm{g} \cdot \mathrm{mL}^{-1}$ of urease ${ }^{11,13}$.
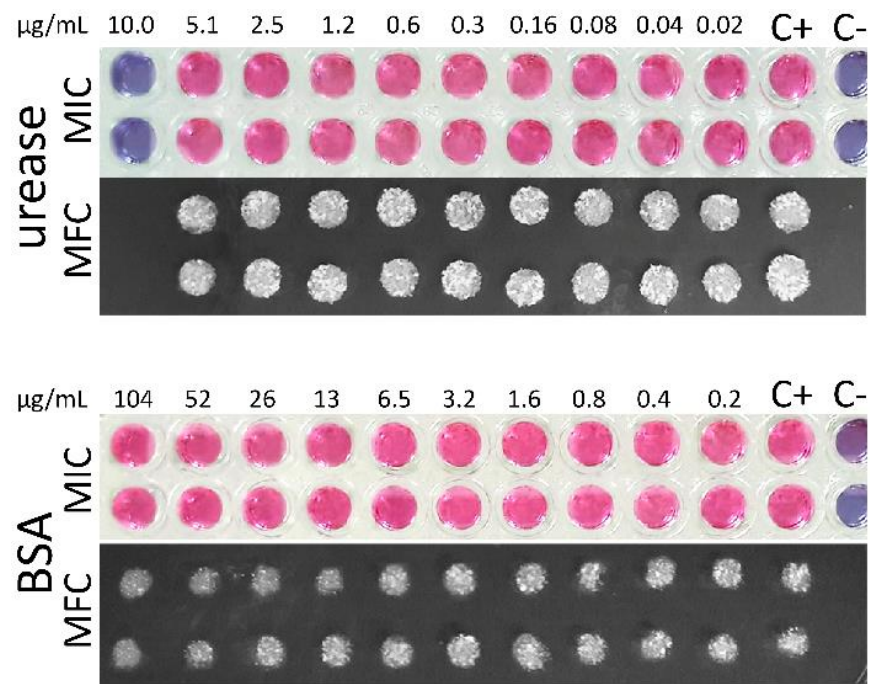

Figure 4. The experimental values of MIC and MFC of GmaxUrease against $\mathrm{Pb} 18$ strain of $P$. brasiliensis. The inoculum concentration was $10^{5} \mathrm{CFU}$ and GmaxUrease concentration ranged between $0.02 \mu \mathrm{g} \cdot \mathrm{mL}^{-1}$ to $10 \mu \mathrm{g} \cdot \mathrm{mL}^{-1}$. The concentration of BSA ranged between 0.2 to $104.4 \mu \mathrm{g} \cdot \mathrm{mL}^{-1}$. Minimal inhibitory concentration is displayed in color and MFC in black/white. Negative control (C-) and positive control $(\mathrm{C}+)$.

\subsection{Modeled structure}

The final model of GmaxUrease shares $92.3 \%$ identity with template from Canavalia ensiformis and presents excellent stereochemical quality with $91.9 \%$ of the residues in the most favored, $7.8 \%$ in the additional allowed and only $0.3 \%$ of the residues in the generously allowed regions of Ramachandran plot, a much better quality than template $(88.3 \%, 11.1 \%$ and $0.6 \%$ respectively). The Fig. $5 \mathrm{a}$ and $\mathrm{b}$ shows the embryo-specific soy urease modeled in this study. The pdb file is provided as supplementary material. Ureases have high homology between different organisms, which indicates common genetic ancestry and similar catalytic action ${ }^{3,6}$. This may justify all residues of catalytic site conserved in GmaxUrease regarding Canavalia ensiformis. However, the three-dimensional structure of ureases varies between organisms and many still need to be clarified ${ }^{10}$. Plants have ureases formed by a single kind of chain with $\sim 90 \mathrm{kDa}$, which form complex trimers $(\alpha 3)$, hexamers $(\alpha 6)$ and, more rarely, dodecamers $(\alpha 12)$, located in the cytosol of plant and fungal cells $s^{2,6,10}$. There are studies indicating that fungitoxic activity of ureases is independent of the catalytic activity ${ }^{1,11}$, being related to the release of peptides with antimicrobial activity when hydrolyzed. It is noteworthy that $P$. brasiliensis has close to 30 to 35 extracellular proteases ${ }^{41}$, which could act on urease, resulting in polypeptides that could be toxic to the fungus. The Fig. 5c shows the alignment of part of the amino acid sequences of plant and microorganisms ureases, plus the recombinant jaburetox peptide identified in the urease of Canavalia ensiformis, considered responsible for the antifungal effect ${ }^{12}$. In GmaxUrease, the homologous sequence corresponds to residues 229 to 269 . It is noteworthy that microorganisms do not have this sequence in their ureases. There are several hypotheses to explain the antifungal mechanism of these peptides, the most likely being due to the reorganization of membrane lipids ${ }^{12}$; however, for GmaxUrease, this mechanism still needs validation assays.

Regardless of the action mechanism, the antifungal property of GmaxUrease against $\mathrm{Pb} 18$, the most virulent strain of $P$. brasiliensis, was clearly demonstrated in this work. Due to the low yield of the protein obtained, it was not possible to perform additional tests in this work. However, the results presented here demonstrate the feasibility for carrying out future studies, aiming at the expression of recombinant GmaxUrease. The soybean is a feedstock widely used in human and animal nutrition and there are no reports of toxic effects in humans regarding the ingestion of urease present in soy. The possibilities for biotechnological use of ureases are wide and can be explored in topical creams formulations for antifungal medicines, especially for oral manifestations of PCM, dermatophytes, as well as a natural preservative in industrialized foods, replacing possible antimicrobial products. This work allows to envision a wide range of research possibilities for the biotechnological applications of soy urease. In addition, despite being an organism of economic and agricultural interest, the notation of soy proteins in the proteomic databases is still very incipient. Many proteins do not have status (sequence of amino acids) confirmed by means of sequencing studies, which include urease. This work helps to improve this notation. 

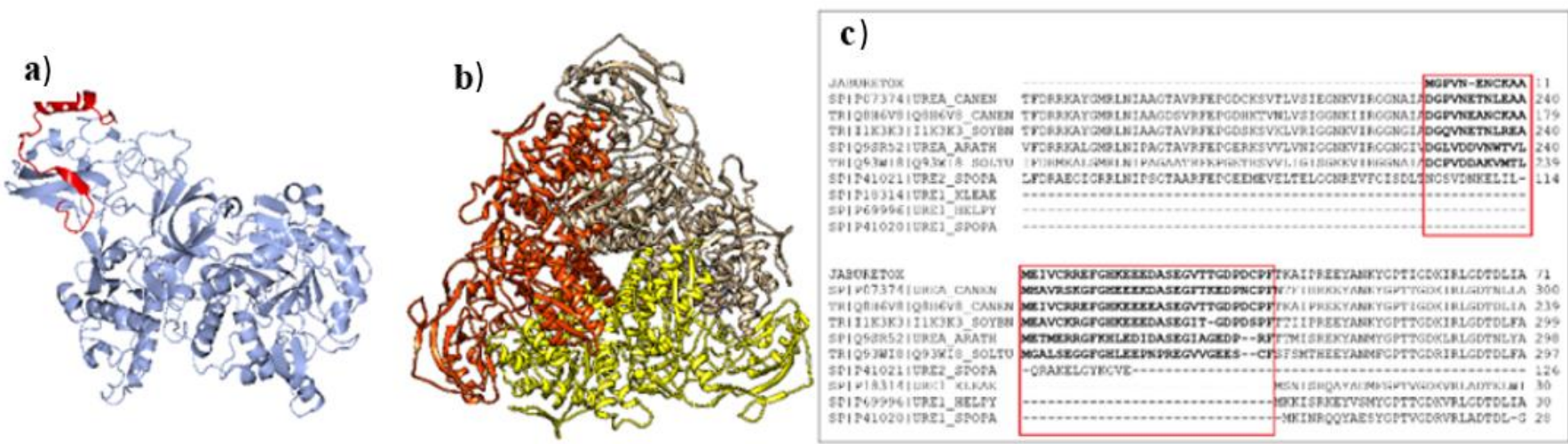

Figure 5. GmaxUrease as structure models and homologs alignment. (a) Ribbon model (blue) of the modeled structure of GmaxUrease. The red segment represents the peptide homolog to jaburetox. (b) Ribbon representation of the biological unity (trimer). (c) Alignment of plant urease sequences: Jaburetox, Canavalia ensiformis (P07374), Canavalia ensiformis JBURE-II (Q8H6V8), Glycine max, this work (I1K3K3), Arabidopsis thaliana (Q9SR52), Solanum tuberosum (Q93WI8). Microorganisms ureases: Sporosarcina pasteurii (P41021), Klebsiella aerogenes, alpha subunit (P18314), Helicobacter pylori, beta subunit (P69996) and Sporosarcina pasteurii, alpha subunit (P41020). The jaburetox peptide present in plant ureases, but absent in bacterial ureases, is highlighted by a red rectangle.

\section{Conclusions}

The embryo-specific soybean urease was extracted and kept its functional properties after centrifugation, gel filtration chromatography and ultrafiltration membrane separation techniques. The results obtained from structural analysis by $\mathrm{LC}^{-M S^{\mathrm{E}}}$, as well as the characterization of the functional catalytic activity, were compatible with those of embryo-specific soy urease. The enzyme has homotrimer as biological unit and, therefore, the structure was modeled by homology in this assembly. In terms of kinetic parameters, the enzyme presented $\mathrm{K}_{\mathrm{M}}$ of $\sim 526 \mathrm{mmol} \mathrm{L}^{-1}$ and $\mathrm{V}_{\max }$ of $7.4 \mathrm{mmol} \mathrm{L}^{-1} \mathrm{NH} 3 \mu \mathrm{g}_{\text {urease }}{ }^{-1} \mathrm{~s}^{-1}$, similar to those from Pisum sativum urease. The extracted protein fraction showed, for the first time, an activity compatible with fungicidal profile (in vitro) against $P$. brasiliensis. We hope to contribute to better understanding the antifungal property of this enzyme, in order to glimpse other possible biotechnological applications.

\section{Acknowledgments}

This work was funded by Fundação Araucária (grant numbers: 40/16 and 53/19), CAPES cod 001, National Council for Scientific and Technological Development (CNPq), Federal Foundation for the Brazilian Research and Development (0673/13-CT-Infra-FINEP) and Complex of Research Support Centers of State University of Maringá (COMCAP-UEM). In particular, we thank professor Márcio Francisco Colombo and João Ruggiero Neto, for their contribution in guiding and training part of the authors of this work, which allowed us to create a research group in biochemistry and molecular biophysics at UEM.

\section{References}

[1] Balasubramanian, A., Durairajpandian, V., Elumalai, S., Mathivanan, N., Munirajan, A. K., Ponnuraj, K., Structural and functional studies on urease from pigeon pea (Cajanus cajan), International Journal of Biological Macromolecules 58 (2013)

301-309.

https://doi.org/10.1016/j.ijbiomac.2013.04.055.

[2] Carlini, C. R., Ligabue-Braun, R., Ureases as multifunctional toxic proteins: A review, Toxicon 110 (2016) 90-109. https://doi.org/10.1016/j.toxicon.2015.11.020.

[3] Kappaun, K., Piovesan, A. R., Carlini, C. R., LigabueBraun, R., Ureases: Historical aspects, catalytic, and noncatalytic properties - A review, Journal of Advanced $\begin{array}{llll}\text { Research } & 13 & \text { (2018) }\end{array}$ https://doi.org/10.1016/j.jare.2018.05.010.

[4] Fisher, K. A., Yarwood, S.A., James, B. R., Soil urease activity and bacterial ureC gene copy numbers: Effect of $\mathrm{pH}$, Geoderma 285 (2017) 1-8. https://doi.org/10.1016/j.geoderma.2016.09.012.

[5] Wessén, E., Nyberg, K., Jansson, J. K., Hallin, S., Responses of bacterial and archaeal ammonia oxidizers to soil organic and fertilizer amendments under long-term management, Applied Soil Ecology 45 (2010) 193-200. https://doi.org/10.1016/j.apsoil.2010.04.003. 
[6] Krajewska, B., Ureases I. Functional, catalytic and kinetic properties: A review, Journal of Molecular Catalysis B: $\quad$ Enzymatic $\quad 59 \quad$ (2009) 9-21. https://doi.org/10.1016/j.molcatb.2009.01.003.

[7] Wiebke-Strohm, B., Ligabue-Braun, R., Rechenmacher, C., De Oliveira-Busatto, L. A., Carlini, C. R., BodaneseZanettini, M. H., Structural and transcriptional characterization of a novel member of the soybean urease gene family, Plant Physiology and Biochemistry 101 (2016) 96-104. https://doi.org/10.1016/j.plaphy.2016.01.023.

[8] Polacco, J. C., Mazzafera, P., Tezotto, T., Opinion Nickel and urease in plants: Still many knowledge gaps, Plant Science 199-200 (2013) 79-90. https://doi.org/10.1016/j.plantsci.2012.10.010.

[9] Follmer, C., Barcellos, G. B. S., Zingali, R. B., Machado, O. L. T., Alves, E. W., Barja-Fidalgo, C., Guimarães, J. A., Carlini, C. R., Canatoxin, a toxic protein from jack beans (Canavalia ensiformis), is a variant form of urease (EC 3.5.1.5): biological effects of urease independent of its ureolytic activity, Biochemical Journal 360 (2001) 217-224. https://doi.org/10.1042/0264-6021:3600217.

[10] Postal, M., Martinelli, A. H. S., Becker-Ritt, A. B., Ligabue-Braun, R., Demartini, D. R., Ribeiro, S. F. F., Pasquali, G., Gomes, V. M., Carlini, C. R., Antifungal properties of Canavalia ensiformis urease and derived peptides, $\quad$ Peptides $38 \quad$ (2012) 22-32. https://doi.org/10.1016/j.peptides.2012.08.010.

[11] Becker-Ritt, A. B., Martinelli, A. H. S., Mitidieri, S., Feder, V., Wassermann, G.E., Santi, L., Vainstein, M. H., Oliveira, J. T. A., Fiuza, L. M., Pasquali, G., Carlini, C. R., Antifungal activity of plant and bacterial ureases, Toxicon $50 \quad$ (2007) 971-983. https://doi.org/10.1016/j.toxicon.2007.07.008.

[12] Martinelli, A. H. S., Kappaun, K., Ligabue-Braun, R., Defferrari, M. S., Piovesan, A. R., Stanisçuaski, F., Demartini, D. R., Dal Belo, C. A., Almeida, C. G. M., Follmer, C., Verli, H., Carlini, C. R., Pasquali, G., Structurefunction studies on jaburetox, a recombinant insecticidal peptide derived from jack bean (Canavalia ensiformis) urease, Biochimica et Biophysica Acta (BBA) - General $\begin{array}{llll}\text { Subjects } & 1840 \quad \text { (2014) 935-944. }\end{array}$ https://doi.org/10.1016/j.bbagen.2013.11.010.

[13] Martinelli, A. H. S., Lopes, F. C., Broll, V., Defferrari, M. S., Ligabue-Braun, R., Kappaun, K., Tichota, D. M., Fruttero, L. L., Moyetta, N. R., Demartini, D. R., Postal, M., Medeiros-Silva, M., Becker-Ritt, A. B., Pasquali, G., Carlini, C. R., Soybean ubiquitous urease with purification facilitator: An addition to the moonlighting studies toolbox, Process Biochemistry $53 \quad$ (2017) 245-258. https://doi.org/10.1016/j.procbio.2016.12.003.
[14] Wanke, B., Aidê, M.A., Capítulo 6 Paracoccidioidomicose, Jornal Brasileiro de Pneumologia 35 (2009) 1245-1249. https://doi.org/10.1590/S180637132009001200013 .

[15] Ferreira, M. S., Paracoccidioidomycosis, Paediatric Respiratory Reviews $10 \quad$ (2009) 161-165. https://doi.org/10.1016/j.prrv.2009.08.001.

[16] Ricci, C.D., Evangelista, C., Tomaz, B.C.A., da Silva, M.V., Barbo, M.L.P., Paracoccidioidomicose: forma crônica cutânea, Revista da Faculade Ciências Médicas Sorocaba 20 (2018) 51. https://doi.org/10.23925/19844840.2018v20i1a12.

[17] Queiroz-Telles, F., Fahal, A. H., Falci, D. R., Caceres, D. H., Chiller, T., Pasqualotto, A. C., Neglected endemic mycoses, The Lancet Infectious Disease 17 (2017) e367e377. https://doi.org/10.1016/S1473-3099(17)30306-7.

[18] Shikanai-Yasuda, M. A., Mendes, R. P., Colombo, A. L., Telles, F. de Q., Kono, A., Paniago, A. M. M., Nathan, A., do Valle, A. C. F., Bagagli, E., Benard, G., Ferreira, M.S ., Teixeira, M. de M., Vergara, M. L. S., Pereira, R. M., Cavalcante, R de S., Hahn, R., Durlacher, R.R., Khoury, Z., de Camargo, Z.P., Moretti, M. L., Martinez, R., II Consenso Brasileiro em Paracoccidioidomicose - 2017, Epidemiologia e Serviços Saúde. 27 (2018). https://doi.org/10.5123/S167949742018000500001.

[19] Borba, J. V. V. B., Tauhata, S. B. F., de Oliveira, C. M. A., Marques, M. F., Bailão, A. M., Soares, C. M. de A., Pereira, M., Chemoproteomic identification of molecular targets of antifungal prototypes, thiosemicarbazide and a camphene derivative of thiosemicarbazide, in Paracoccidioides brasiliensis, PLoS One. 13 (2018) e0201948. https://doi.org/10.1371/journal.pone.0201948.

[20] Nicola, A. M., Albuquerque, P., Paes, H. C., Fernandes, L., Costa, F. F., Kioshima, E. S., Abadio, A. K. R., Bocca, A. L., Felipe, M. S., Antifungal drugs: New insights in research \& development, Pharmacology \& Therapeutics 195 (2019) 21-38. https://doi.org/10.1016/j.pharmthera.2018.10.008.

[21] Bracco, L. F., Levin, G. J., Urtasun, N., del Cañizo, A. A. N., Wolman, F. J., Miranda, M. V., Cascone, O., Covalent immobilization of soybean seed hull urease on chitosan mini-spheres and the impact on their properties, Biocatalysis and Agricultural Biotechnology 18 (2019) 101093. https://doi.org/10.1016/j.bcab.2019.101093.

[22] Laemmli, U. K., Cleavage of Structural Proteins during the Assembly of the Head of Bacteriophage T4, Nature 227 (1970) 680-685. https://doi.org/10.1038/227680a0.

[23] Bradford, M. M., A rapid and sensitive method for the quantitation of microgram quantities of protein utilizing the 
principle of protein-dye binding, Analytical Biochemistry 72 (1976) 248-254. https://doi.org/10.1006/abio.1976.9999.

[24] Bzura, J., Koncki, R., A mechanized urease activity assay, Enzyme and Microbial Technology 123 (2019) 1-7. https://doi.org/10.1016/j.enzmictec.2019.01.001.

[25] El-Hefnawy M. E., Sakran, M., Ismail, A. I., Aboelfetoh, E., Extraction, purification, kinetic and thermodynamic properties of urease from germinating Pisum Sativum L. seeds, BMC Biochemistry 15 (2014) 15. https://doi.org/10.1186/1471-2091-15-15.

[26] Shevchenko, A., Jensen, O. N., Podtelejnikov, A. V., Sagliocco, F., Wilm, M., Vorm, O., Mortensen, P., Shevchenko, A., Boucherie, H., Mann, M., Linking genome and proteome by mass spectrometry: Large-scale identification of yeast proteins from two dimensional gels, Proceedings of the National Academy of Sciences of the United States of America 93 (1996) 14440-14445. https://doi.org/10.1073/pnas.93.25.14440.

[27] Shevchenko, A., Wilm, M., Vorm, O., Mann, M., Mass Spectrometric Sequencing of Proteins from Silver-Stained Polyacrylamide Gels, Analytical Chemistry 68 (1996) 850858. https://doi.org/10.1021/ac950914h.

[28] Balasubramanian, A., Ponnuraj, K., Crystal Structure of the First Plant Urease from Jack Bean: 83 Years of Journey from Its First Crystal to Molecular Structure, Journal of Molecular Biology $400 \quad$ (2010) 274-283. https://doi.org/10.1016/j.jmb.2010.05.009.

[29] Webb, B., Sali, A., Comparative Protein Structure Modeling Using MODELLER, Current Protocols in Bioinformatics 54 (2016). https://doi.org/10.1002/cpbi.3.

[30] Collaborative Computational Project Number 4, The CCP4 suite: programs for protein crystallography, Acta Crystallographica Section D Structural Biology 50 (1994) 760-763. https://doi.org/10.1107/S0907444994003112.

[31] Britton, H. T. S., Robinson, R. A., CXCVIIIUniversal buffer solutions and the dissociation constant of veronal, Journal of the Chemical Society (1931) 1456-1462. https://doi.org/10.1039/JR9310001456.

[32] CLSI, Método de Referência para Testes de Diluição em Caldo para a Determinação da Sensibilidade a Terapia Antifúngica das Leveduras, 22 (2002) 1-50.

[33] Wayne, P. A., CLSI. Performance Standards for Antimicrobial Susceptibility Testing; Twenty-second Informational supplement. CLSI document M100-S22. Clinical and Laboratory Standards Institute, 2015.

[34] Rodrigues-Vendramini, F. A. V., Faria, D. R., Arita, G. S., Capoci, I. R. G., Sakita, K. M., Caparroz-Assef, S. M., Becker, T. C. A., Bonfim-Mendonça, P. S., Felipe, M. S.,
Svidzinski, T. I. E., Maigret, B., Kioshima, É. S., Antifungal activity of two oxadiazole compounds for the paracoccidioidomycosis treatment, PLoS Neglected Tropical $\begin{array}{llll}\text { Diseases } & 13 & \text { (2019) } & \text { e0007441. }\end{array}$ https://doi.org/10.1371/journal.pntd.0007441.

[35] Rodrigues-Vendramini, F. A. V., Marschalk, C., Toplak, M., Macheroux, P., Bonfim-Mendonça, P. S., Svidzinski, P. T. I. E., Seixas, F. A. V., Kioshima, E. S., Promising New Antifungal Treatment Targeting Chorismate Synthase from Paracoccidioides brasiliensis, Antimicrobial Agents and Chemotherapy 63 (2018) e01097-18. https://doi.org/10.1128/AAC.01097-18.

[36] Polacco, J. C., Havir, E. A., Comparisons of soybean urease isolated from seed and tissue culture., Journal of Biological Chemistry, 254 (1979) 1707-1715.

[37] Polacco, J. C., Thomas, A. L., Bledsoe, P. J., A Soybean Seed Urease-Null Produces Urease in Cell Culture, Plant Physiology $69 \quad$ (1982) 1233-1240. https://doi.org/10.1104/pp.69.5.1233.

[38] Torisky, R. S., Polacco, J. C., Soybean Roots Retain the Seed Urease Isozyme Synthesized during Embryo Development, Plant Physiology 94 (1990) 681-689. https://doi.org/10.1104/pp.94.2.681.

[39] Polacco, J. C., Winkler, R. G., Soybean Leaf Urease: A Seed Enzyme?, Plant Physiology 74 (1984) 800-803. https://doi.org/10.1104/pp.74.4.800.

[40] Yoo, Y. J., Feng, Y., Kim, Y.-H., Yagonia, C. F. J., Fundamentals of Enzyme Engineering, New York, Springer, 2017. https://doi.org/10.1007/978-94-024-1026-6.

[41] Desjardins, C. A., Champion, M. D., Holder, J. W., Muszewska, A., Goldberg, J., Bailão, A. M., Brigido M. M., Ferreira, M. E. S., Garcia, A. M., Grynberg, M., Gujja, S., Heiman, D. I., Henn, M. R., Kodira, C. D., León-Narváez, H., Longo, L. V. G., Ma, L.-J., Malavazi, I., Matsuo, A. L., Morais, F. V., Pereira, M., Rodriguéz-Brito, S., Sakthikumar, S., Salem-Izacc, S. M., Sykes, S. M., Teixeira, M. M., Vallejo, M. C., Walter, M. E. M. T., Yandava, C., Young, S., Zeng, Q., Zucker, J., Felipe, M. S., Goldman, G. H., Haas, B. J., McEwan, J. G., Nino-Vega, G., Puccia, R., San-Blas, G., Soares, C. M. A., Birres, B. W., Cuomo, C. A., Comparative Genomic Analysis of Human Fungal Pathogens Causing Paracoccidioidomycosis, PLoS Genetics 7 (2011) e1002345. https://doi.org/10.1371/journal.pgen.1002345. 